TANULMÁNYOK 2019/2. Bölcsészettudományi Kar, Újvidék

STUDIJE 2019/2. Filozofski fakultet, Novi Sad

STUDIES 2019/2. Faculty of Philosophy, Novi Sad

ETO: $342.725(497.11)$

ORIGINAL SCIENTIFIC PAPER

$323.15(497.11)$

341.4

DOI: $10.19090 / \mathrm{tm} .2019 .2 .41-58$

A kézirat leadásának időpontja: 2019. október 31.

Közlésre elfogadva: 2019. november 2.

\author{
BERETKA Katinka \\ Union Egyetem, Dr. Lazar Vrkatić Jogi és Üzleti Tanulmányok Kara \\ Újvidék, Szerbia \\ beretka.katinka@gmail.com
}

\title{
A NYELVI JOGSÉRTÉSEK \\ SZANKCIONÁLHATÓSÁGÁNAK TÉTELES JOGI ÉS NEMZETKÖZI JOGI DIMENZIÓI
}

\section{Mogućnosti sankcionisanja povreda jezičkih prava u pozitivnom i međunarodnom pravu}

\section{Probability of Sanction Imposition for Violation of Linguistic Rights in Domestic and International Law}

\begin{abstract}
A tanulmány a jogtudomány módszereivel mutatja be a szerbiai nyelvi jogi szabályozást és az ezen szabályok megsértésének szankcióit, illetve egyéb negatív jogkövetkezményeit, különösképpen a nemzeti kisebbségek hivatalos nyelvhasználatának szemszögéből, mind a tételes jog, mind pedig a nemzetközi jog által lefektetett keretek között. A sokat és egyes elemeiben méltán dicsért szerbiai nyelvi jogok nagy vonalakban történő ismertetése mellett a hangsúly az esetleges büntető rendelkezések, illetve azok hatékonyságának kritikai analízisén van, figyelemmel arra a nem éppen kedvező gyakorlatra Szerbiában, hogy sok esetben a jogsértő magatartás semmilyen következményt nem von maga után a jogszegőre nézve. A cél összegyűjteni azon jogszabályhelyeket, amelyek valamilyen szankciót, felelösségre vonást írnak elő a nyelvi jogsértések esetére, és lehetôség szerint értékelni azok eredményességét a nemzeti kisebbségek nyelvi jogérvényesítésének folyamatában.
\end{abstract}

Kulcsszavak: nyelvi jogok, nemzeti kisebbségek, jogsértés, szankció, Szerbia 


\section{Bevezetö}

Az utóbbi években a vezető politikai retorikában gyakran hallani Szerbia kivételes nemzeti kisebbségpolitikájáról, a kisebbségi jogok elért szintjéről és az itt élő nemzetiségek ${ }^{1}$ kiváltságos helyzetéről a régió többi országához képest (Bartha 2019, MTI 2019a, MTI 2019b, Ismeretlen 2018). Természetesen a mindezen kijelentések mögött húzódó politikai motiváción túl Szerbiában kétségtelenül a kisebbségi jogok viszonylag magas standardjaival találkozunk, amelyek részben a valamikori Jugoszlávia többnyelvűségi, multikulturális hagyományaira épülnek (Korhecz 2009, 1315). A nemzeti/többségi nyelv eröteljes jogi védelme és a nemzetiségi nyelvhasználat többségi nyelv „kárára” történő használatának szankcionálása helyett (melyre a szlovákiai jogalkotásban találunk viszonylag friss példát) Szerbia széles körü nemzetiségi nyelvi jogokat garantál, amelyeket - az adott nyelv státusától függően - akár a szerb nyelvvel párhuzamosan, egyenlő elvek mentén is gyakorolni lehet. A kisebbségbarát jogalkotást (amely jelzőt mindenképpen bizonyos fenntartásokkal kell értelmezni) azonban nem feltétlenül kíséri kisebbségbarát gyakorlat is, amelyre évekre visszamenőleg a nemzetközi szervezetek, az Európai Bizottság országjelentései is folyamatosan felhívják a közvélemény figyelmét. Ezért felmerül a kérdés, hogy a nyelvi jogok gyakorlati megvalósulása során tapasztalt nehézségeket, akár az érvényesülésük ellehetetlenülését milyen jogi mechanizmusokkal lehet korrigálni, szükség szerint szankcionálni a szerbiai jogrendszerben.

Jelen tanulmányban a szerbiai nemzeti kisebbségek részére garantált, a következőkben nagy vonalakban bemutatott nyelvi, nyelvhasználati jogok megsértésének jogkövetkezményeivel foglalkozunk, pontosabban azt vizsgáljuk, milyen büntető rendelkezéseket írt elő a jogalkotó a nyelvi jogsértések esetére, elsősorban a hivatalos nyelvhasználat terén, és összességében arra keressük a választ, hogy mindezekre való tekintettel mennyire (lehet) hatékony a nyelvi jogvédelem az országban.

\section{A hivatalos nyelvhasználathoz füzödö jogok Szerbiában, különösen a lehetséges jogsértések szemszögéböl}

Szerbiában nincs kötelező államnyelv. A hivatalos értekezésben elsősorban a szerb nyelv és a cirill írásmód a használatos, azonban törvénnyel egyéb (minden bizonnyal nemzetiségi) nyelvek hivatalos használata is szabályozható,

\footnotetext{
A tanulmányban a szerző egymás szinonimájaként használja a nemzeti kisebbség, a nemzetiség és a kisebbség kifejezéseket, miközben a szerbiai jogterminológiában, valamint a hivatalos értekezésben kizárólag a nemzeti kisebbség (nacionalne manjine) kifejezés a használatos.
} 
az alkotmány alapján (A Szerb Köztársaság Alkotmánya 2006: 10. szakasz). ${ }^{2}$ Ez különösen magában foglalja általánosságban véve a saját nyelv és írásmód használatát, az eljárások lefolytatását az állami, tartományi, önkormányzati, illetve egyéb közmegbízatást gyakorló szervek előtt kisebbségi nyelven, valamint a hagyományos helységnevek és egyéb topográfiai jelek kitüzését nemzetiségi nyelven mindazokon a területeken, ahol az adott kisebbségi közösség jelentős számban él, illetve a saját nyelvü névhasználatot (A Szerb Köztársaság Alkotmánya 2006: 79. szakasz 1. bekezdés). Az alkotmány azonban egyéb kisebbségi, nem kizárólagosan nyelvi, de nyelvi jellegü jogokat is garantál, mint amilyen az anyanyelvü oktatáshoz, valamint tájékoztatáshoz való jog.

Természetesen egyes nyelvi jogok mindenkit megilletnek az országban, nemzetiségi, kisebbségi, állampolgársági státustól függetlenül, mint amilyen a letartóztatott személynek (27. szakasz 2 . bekezdés), illetve a büncselekmény elkövetésével terheltnek a számára érthető nyelven történő tájékoztatása a terhére rótt vádakról és az ôt megillető jogokról (33. szakasz 1. bekezdés), a saját nyelv használatának a joga (tolmács közremüködésével) a bíróság, egyéb állami szerv és közmegbízatással felruházott szervezet előtti eljárásban (199. szakasz 1. bekezdés). Ezek azonban nem képezik a vizsgálódásunk szűkebb tárgyát. Fontos tehát megkülönböztetni az általános nyelvi jogokat a kizárólag a nemzeti kisebbségeknek garantált nyelvi jogoktól, vagyis a hivatalos értekezést érintő kérdésekben különbséget tenni az idegen nyelv és a hivatalos használatban lévő (akár nemzetiségi, akár nemzeti - többségi) nyelv között.

Másrészről viszont, az emberi jogok nagy része szorosan kapcsolódik a nyelvszabadság kérdésköréhez, amely voltaképpen azt jelenti, hogy sem a nemzeti többség, sem pedig a nemzeti kisebbségek számára nem lehetséges bizonyos emberi jogok kifogástalan érvényesítése a saját nyelvük (illetve az általuk szabadon választott nyelv) használatára való jog egyetemes elismerése nélkül. Például, mit ér a kifejezés szabadsága a nyelvhasználat, a nyelv szabadsága nélkül (Andrássy 2013, 12). Ez alapján pedig bármely emberi jog megsértése, amely gyakorlása, illetve korlátozása valamilyen módon az anyanyelv szabad használatához is kapcsolódik, nyelvi jogsértésnek tekinthető. Továbbá a nyelvszabadság azt is feltételezi, hogy a nemzeti többség, esetünkben a szerb nemzet nyelv- és íráshasználatát (a szerb nyelvet és a cirill, tehát nem a latin írásmódot) is külön rendelkezésekkel kell védeni, és szükség szerint annak megsértését szankcionálni - bár az nem történhet a nemzeti kisebbségi nyelvi jogok kárára. Az alkotmánybíróság, a példa kedvéért, alkotmány- és törvényellenesnek minősí-

\footnotetext{
${ }^{2}$ A tanulmány föszövegében hivatkozott jogszabályok aktuális közlönyállapotát, illetve eredeti szerb nyelvü megnevezését az irodalomjegyzék tartalmazza.
} 
tette Nagybecskerek statútumának azon rendelkezését, amellyel a latin írásmód általános használatát írta elő az önkormányzat területén, kiegyenlítve annak státusát a cirill írásmódéval (IU 294/2002. ügyszámú, 2005. február 24-én kelt alkotmánybírósági határozat).

Habár az alkotmány által garantált kisebbségi jogokat közvetlenül kell alkalmazni, a törvényhozó elöírhatja az érvényesítésük konkrét körülményeit, amennyiben erre alkotmányos felhatalmazást kap, vagy az az adott jog érvényesülésének természetére való tekintettel elkerülhetetlen (A Szerb Köztársaság Alkotmánya 2006: 18. szakasz). Ennek megfelelően több tíz ágazati törvény szabályozza a nemzeti kisebbségek nyelvi jogait az egyes társadalmi területeken; de figyelemmel a jelen tanulmány témájára, a továbbiakban csak a hivatalos nyelvhasználat terén felmerülő jogokról lesz szó.

A nemzetiségi nyelvhasználat elsődleges jogi keretét, az alkotmány mellett, a nemzeti kisebbségek jogainak és szabadságainak védelméről szóló, valamikori szövetségi törvény (továbbiakban Kisebbségvédelmi törvény), illetve a hivatalos nyelv- és íráshasználatról szóló törvény tartalmazza, de ahogyan említettük is, különböző nyelvi jogi rendelkezések találhatóak még az eljárásjogi törvényekben (büntető, perrendtartás, közigazgatási eljárás és közigazgatási per), a választási törvényekben, a helyi önkormányzati, a tartományi hatásköri, a közjegyzőségről, az anyakönyvekről, a pecséthasználatról szóló törvényben stb. A kisebbségeknek garantált nyelvhasználati jogok érvényesítésének első lépcsőfokát mégis a községi, városi statútumok képezik, ugyanis egy nemzetiségi nyelv akkor válik a szerb nyelvvel egyenrangúvá, illetve hivatalossá az egyes állami, államigazgatási, önkormányzati szervek munkájában, ha azt az adott helyi önkormányzat az alapszabályába bevezeti. Ennek feltétele, hogy a nemzetiség a helyi lakosság legalább 15\%-át képezze az utolsó népszámlálási adatok szerint. Az ily módon hivatalossá vált nemzeti kisebbségi nyelvet ezt követően valamennyi, az adott helyi önkormányzat területén müködő szervnek a szerb nyelvvel egyenrangú feltételek mellett kell használnia, az adott szerv, szervezet székhelyétől függetlenül, legyen szó a szóbeli és írásbeli ügyfél-kommunikációról, az eljárások lefolytatásáról, az ürlaphasználatról, a nyilvántartások vezetéséről és a közokiratok kiállításáról, a választási anyagokról, a képviselő-testületi munkáról, illetve a vizuális nyelvhasználatról (szervezetek névtáblái, helységnévtáblák, topográfiai jelek, útirányjelzők stb.) (Kisebbségvédelmi törvény 2018: 11. szakasz 1-5. bekezdés; Törvény a hivatalos nyelv- és íráshasználatról 2018: 11. szakasz 1-4. bekezdés). A kisebbségi nyelv vizuális megjelenítése azonban azokon a településeken is törvényszerü, amelyekben bár az adott közösség nyelve nem hivatalos, tehát a számaránya a teljes község/város területén nem éri el a 15\%-ot, viszont ennek a jognak az elismerését a községi statútumban a nemzeti kisebbségi tanács 
előzetes véleménye, illetve a közösség hagyományos jelenléte az adott településen indokolttá teszi (Kisebbségvédelmi törvény 2018: 11. szakasz 1-5. bekezdés; Törvény a hivatalos nyelv- és íráshasználatról 2018: 11. szakasz 6-7. bekezdés).

A nyelvhasználati törvény a nyelvi kérdések vonatkozásában kerettörvény jellegü, tehát kiindulópontként szolgál a nyelvi rendelkezéseket csak járulékosan szabályozó ágazati törvények részére. Ettől függetlenül azonban a gyakorlat azt mutatja, hogy az ágazati törvények nemcsak eltérnek a nyelvhasználati törvény szabályozásától, hanem sokszor azzal ellentétesen, szűkítően írják elő a nemzetiségi nyelvhasználati jogokat. Ez a kollízió már önmagában is sérti a joguralom alappilléreinek egyikét, a jogbiztonság elvét, de egyben teret szolgáltathat a nemzeti kisebbségekre nézve kedvezőtlen eseti jogértelmezéseknek is. Ennek egyik tipikus iskolapéldája az anyakönyvek vezetése. A nyelvhasználati törvény elöírja, hogy azon helyi önkormányzatokban, amelyek területén a kisebbségi nyelv hivatalos használatban van, a hivatalos nyilvántartásokat, mint amilyen maga az anyakönyv is, nemzetiségi nyelven is kell vezetni (Törvény a hivatalos nyelv- és íráshasználatról 2018: 11. szakasz 3. bekezdés, 18. szakasz 2. bekezdés). Az anyakönyvekről szóló törvény ezzel szemben explicit verbis kimondja, hogy az anyakönyvekben az adatok szerb nyelven, cirill írásmóddal szerepelnek (Törvény az anyakönyvekröl 2018: 16. szakasz), és ettől egyedül a személynevek esetében lehet eltérni (17. szakasz). Mivel a szerbiai jogrendben nincs különbség törvény és törvény között, és a tételes jogban kimondottan nem létezik a kerettörvény fogalma sem, felmerül a kérdés, voltaképpen melyik törvényhelyet kell alkalmazni. Kiindulva a lex specialis derogat legi generali elvböl (jelentése: a különös rendelkezés lerontja az általánost) a bíróság valószínűleg az anyakönyvekről szóló törvénynek adna elsőbbséget, függetlenül attól, hogy egyrészt, mindkét törvény különös (értsd ágazati, speciális) a maga nemében, másrészt, a kisebbségi jogokat is érintő rendelkezéseket mindig a demokratikus társadalom értékeinek előmozdítására való tekintettel kell értelmezni (A Szerb Köztársaság Alkotmánya 2006: 18. szakasz 3. bekezdés). Ez utóbbi azonban jogi szempontból túlságosan is általános követelmény (Venice Commission 2007, 7), és valójában mind a formális jogegyenlőség, mind pedig a kisebbségi külön jogokat magába foglaló valós jogegyenlőség biztosítása egyaránt megfeleltethető a modern nyugati típusú demokráciák értékfelfogásának. Ami a példaként említett konkrét törvénykollízióból eredő egyéni jogsértéseket illeti, a Nagykikindai Városi Közigazgatási Hivatal elutasította a nyelvhasználati törvény által jogként garantált többnyelvü (azaz szerb és hivatalos használatban lévő nemzeti kisebbségi nyelvü, adott esetben magyar nyelvü) anyakönyvi kivonat kiállítását, mert azt csak „hazai ürlapon, cirill nyelven” kaphatja meg az ügyfél. A konkrét esetben egyébként a kétnyelvü kivonat és a kétnyelvü űllapon nyomtatott kivonat 
fogalomzavara is megjelent. Ugyanis amíg az anyakönyvek vezetését szabályozó utasítás elöírja a szerb nyelvü adatok kétnyelvü ürlapon történő feltüntetésének a lehetőségét azon önkormányzatokban, ahol a nemzeti kisebbségi nyelv hivatalos használatban van (Utasítás az anyakönyvek vezetéséről és az anyakönyvek nyomtatványairól 2018: 137. pont), addig a nyelvhasználati törvény alapján nemcsak az ürlap, de magának a teljes tartalomnak a „többnyelvüsítésére” is lehetőség van. A tartományi ombudsman ezzel szemben csak arra utasította a nagykikindai hivatalt, hogy szerezzen be megfelelö mennyiségü kétnyelvü ürlapot a hasonló jogsértések elkerülésére a jövőben, amelyeket a kisebbségi nyelven anyakönyvezett személynéven kívül a törvénnyel és az utasítással összhangban szerb nyelven tölt majd ki. A véleményben az ombudsman a kétnyelvü tartalmú anyakönyvi kivonatok gyakorlatát a 2014-ben hatályon kívül helyezett többnyelvü anyakönyvi kivonatokra vonatkozó tartományi rendelethez kötötte, teljesen figyelmen kívül hagyva a nyelvhasználati törvény egyébként hatályos rendelkezéseit (Tartományi Polgári Jogvédő - Ombudsman 2019, 35-36). ${ }^{3}$

Szerbiában a vertikális hatalommegosztás következő szintjét Vajdaság Autonóm Tartomány foglalja el, amely alkotmányos felhatalmazása alapján többlet (nyelvi) jogokat teremthet a területén élő nemzeti kisebbségek számára, a törvényekkel összhangban (A Szerb Köztársaság Alkotmánya 2006: 79. szakasz 2. bekezdés). Részben az idevágó nem egységes alkotmánybírósági gyakorlat miatt azonban a mai napig tisztázatlan, valójában mi képezheti a tartományi jogalkotás törvényi alapját. Például a bíróság szerint Vajdaság AT a hivatalos nyelvhasználat terén nem, ezzel szemben a nemzetiségi nyelvü (felső)oktatás terén igenis teremthet a törvényben nem kifejezetten szereplö, azaz addig nem létező jogokat a kisebbségvédelmi törvény rendelkezései alapján (Beretka 2018, 157). Ez a dilemma külön hangsúlyt kapott az utóbbi években, amikor az Újvidéki Egyetem Jogtudományi Kara elutasította a nemzetiségi nyelvü felvételi vizsgák megszervezését. Egyrészt évekre ellehetetlenült egy tartományi jogszabályokkal garantált kisebbségi nyelvi jog gyakorlása, másrészt egy sor kérdés merült fel annak vonatkozásában, milyen jogvédelmet kell biztosítani a nem törvénnyel, hanem törvénytől alacsonyabb rangú aktusokkal szavatolt (kisebbségi) jogok

\footnotetext{
${ }^{3}$ Vajdaságban változó volt a közigazgatási hivatalok gyakorlata: egyes helyeken a szerb nyelvet favorizáló anyakönyvekről szóló törvény, míg másutt a kisebbségbarát(ibb) nyelvhasználati törvény szerint jártak el. 2019. január 1-jétől azonban központosított irányítás alá vonták az anyakönyvek vezetését, amely voltaképpen megszüntette a szelektíven alkalmazott jó gyakorlatot is. Miután azonban a tartalmában (is) kétnyelvű kivonat mindenben megegyezik a szerb nyelvü változattal (végeredményben szó szerinti fordításról van szó), nem ad hozzá, nem vesz el belőle, és ily módon az anyakönyvvezetés integritását sem sérti, 2019 áprilisában a törvénykollíziót áthidaló megoldásként az államigazgatási minisztérium utasítást közölt a kétnyelvű kivonatok igénylésének módjáról és az eljárás menetéről (Rúzsa 2019).
} 
megsértésének alkalmával (Beretka 2019, 65-66). Az alkotmánybíróság normakontroll keretében kimondta, hogy a nemzetiségi nyelvü felvételi vizsgát előíró tartományi jogszabály se nem alkotmány-, se nem törvényellenes (IUo 199/2013. ügyszámú, 2015. április 20 -án kelt alkotmánybírósági határozat), a nyelvi alapú diszkrimináció miatt indított bírósági eljárások során mégis több ízben elhangzott, hogy a tartományi jogszabállyal teremtett jogoknak nem feltétlenül lehet bírósági jogvédelmet biztosítani; hanem a mindenkori tartományi közigazgatás feladata lenne, hogy ellenőrizze a tartományi elöírások tiszteletben tartását.

A továbbiakban az egyes jogsértési szituációkat illusztrálva mutatjuk be a szerbiai tételes jogot, illetve a két legjelentősebb nemzeti kisebbségi nemzetközi egyezményt, kihangsúlyozva a jogsértésekhez rendelt jogkövetkezmények jellegzetességeit és a jogvédelmi mechanizmus hatékonyságát.

\section{Negatív jogkövetkezmények nyelvi jogsértések esetén}

Az általános definíció szerint a jogsértés legalább egy jogi normával ellentétes emberi magatartás, azonban ez nem szükségszerúen jelenti szankció alkalmazását is a jogszegővel szemben. A jogszabályok rendszerint három szerkezeti elemből állnak: tényállásból (hipotézis), rendelkező részből (diszpozíció) és jogkövetkezményből. Ez utóbbi jellegétől függően pedig lehet negatív vagy pozitív következmény, azaz büntetés vagy jutalom, esetleg egyéb kedvező joghatás, például kitüntetés. Ma már a jogszabályok nagy részét szankcióval látja el a jogalkotó javarészben az ún. büntetö rendelkezések című fejezetben, azonban az is előfordul, hogy más általános aktus, sőt akár másik jogág tartalmazza a jogsértéskor alkalmazandó szankciót. Más részről, „[a] szankciók hiánya címén még nem vitatható el valamely szabály jogi jellege, viszont a leghatásosabb szankciókkal ellátott szabály sem okvetlenül jogszabály" (Bibó 1934, 4).

A jogszabályokat a szankciók súlyossága, azaz a negatív jogkövetkezmények típusa szerint a következöképpen csoportosíthatjuk: 1) lex imperfecta - olyan jogszabály, amely megszegése nem von maga után sem polgári jogi (érvénytelenség, semmisség), sem pedig büntető jogi szankciót (büntetés); 2) lex perfecta a jogsértés következménye csak polgári jogi érvénytelenség (értsd, a törvényellenes magatartás semmis); 3) lex plus quam perfecta - jogszabályellenes magatartás jogilag érvénytelen és egyben büntetendő és végezetül 4) lex minus quam perfecta - a tilalom megszegését büntetéssel sújtja, de az illető jogcselekmény érvényét nem érinti (Korkunov 2000, 248). A nyelvi jogokat szabályozó szerbiai aktusokat nem tudnánk kizárólagosan egy, fenti kategória alá besorolni, azonban kétségtelen, hogy a legtöbbször legfeljebb magát a törvényellenes magatartást sikerül(het) érvénytelenné nyilvánítani, a jogszegő közvetlen büntetése nélkül. 
Pedig a tételes jog számtalan lehetőséggel rendelkezik, hogy az enyhétől a súlyos jogsértésig differenciálja a szankciók különböző fajtáit. Ezzel szemben „[a] nemzetközi jog az a jogterület, amely ma még legkevésbé tudja igénybe venni a szankciók segítségét" (Bibó 1934, 5). Ez a kisebbségi nyelvi jogok esetében még kifejezettebben jelen van, hiszen a nemzeti kisebbségi jogok elsősorban a soft law („puha jog”) nemzetközi szabályozás tárgyát képezik, azaz a jog általános eszközeit tekintve hagyományos módon nem vagy nehezen érvényesíthetők. Általában az országok nem kötelező jellegű vállalásairól van szó, amelyek egyaránt tekinthetők kvázi jogi normáknak, mint tisztán politikai ígéreteknek (Guzman-Meyer 2010). Ilyen soft law jellegü norma tipikusan a nemzeti kisebbségek védelméről szóló keretegyezmény egyik nyelvi jogi rendelkezése is, mely értelmében elegendő, ha a felek csak erőfeszitéseket tesznek, hogy lehetőség szerint biztosítsák a közigazgatási hatóságok előtti kisebbségi nyelvhasználatot elösegitő feltételeket. ${ }^{4}$

Szerbia mindkét, nyelvi jogi szempontból releváns európai tanácsi (ET) dokumentumot, közismert nevükön a kisebbségvédelmi keretegyezményt és az európai nyelvi kartát becikkelyezte..$^{5}$ A keretegyezmény harmadik monitoringciklusában elfogadott határozat értelmében Szerbiában a lakosság körében viszonylag magas szintü szimpátia övezi a nemzeti kisebbségek nyelvi jogainak védelmét, és az idevágó rasszista incidensek száma is csökkent az elmúlt években. ${ }^{6}$ Az ajánlások azonban elsősorban a kisebbségi nyelvü oktatás, média kérdéseivel foglalkoznak, a hivatalos nyelvhasználatnak pedig csak néhány szegmensét vizsgálják: a névhasználatot, a topográfiai jelzésekkel kapcsolatos állapotot, illetve a kisebbségi nyelvismerettel rendelkező közalkalmazottak alkalmazásának szükségességét a helyi önkormányzati szervekben (Council of Europe - Committee of Ministers 2015); amely egyébként a keretegyezmény igen szűkre szabott nyelvi jogi tartalmú rendelkezéseiből is következik. A keretegyezményben vállaltak nem teljesítésekor a szakértői testület ajánlásokat fogalmaz meg a részes államnak a

\footnotetext{
${ }^{4}$ „A nemzeti kisebbségekhez tartozó személyek által hagyományosan, vagy jelentősebb számban lakott területeken, amennyiben azok a személyek úgy kívánják, vagy az ilyen kívánság megfelel a valóságos szükségnek, a Felek erőfeszítéseket tesznek arra, hogy biztosítsák - lehetőség szerint - e személyek és a közigazgatási hatóságok közötti kisebbségi nyelv használatát elősegítő feltételeket." Keretegyezmény a Nemzeti Kisebbségek Védelméről, 10(2) cikk.

${ }^{5}$ Törvény a nemzeti kisebbségek védelméről szóló keretegyezmény megerősítéséről, JSZK Hivatalos Lapja - Nemzetközi szerzödések, 6/98. szám; Törvény a regionális vagy kisebbségi nyelvek európai kartájának becikkelyezéséről, Szerbia és Montenegró Hivatalos Lapja - Nemzetközi szerződések, 18/2005. szám.

${ }^{6}$ A jelenleg futó negyedik monitoringciklusban az ET Kisebbségvédelmi Keretegyezménye Tanácsadó Bizottságának szerbiai látogatása 2019. március 18. és 22. között volt esedékes, melynek eredményei még nem nyilvánosak. https://www.coe.int/en/web/minorities/serbia (2019. okt. 22.)
} 
jogsértések elhárítására, amelyek az országjelentéssel együtt egyfajta iránymutatásként, objektív standardként szolgálnak az adott ország részére (Fiala-Butora 2018, 8), azonban ezen kontrollmechanizmus hatásfoka inkább csak politikai módszerekkel mérhető: „A kisebbségvédelmi mechanizmusok elvileg önálló nemzetközi garanciarendszer nélkül is müködhetnének, a tapasztalat azonban azt mutatja, hogy a nemzetközi jog, és adott esetben a hatalmi politika, gyakran ki tudta kényszeríteni olyan belső, állami lépések meghozatalát, amelyre az állam-, illetve rendszerint a nemzetállam önmagától nem volt hajlandó" (Kovács 1995). Ugyanez mondható el az ET másik kisebbségeket is érintő egyezményéről.

A regionális vagy kisebbségi nyelvek európai kartájából à la carte módon vállalható kötelezettségek megfogalmazása (például a felek bátorítják és/vagy megkönnyítik, gondoskodnak róla, megteszik a megfelelő intézkedéseket, támogatják) szintén nagy mozgásteret enged a részes államoknak a karta végrehajtása során. És a monitoringciklus végén a Miniszteri Bizottság által megfogalmazott ajánlás jellegéből kifolyólag ugyancsak nem kötelezi (szankcionálható módon) az adott államot - akár csak a keretegyezmény esetében. Ez egyébként magának a Szerbiára vonatkozó ajánlásnak a szóhasználatából is visszaköszön. Például a Miniszteri Bizottság ,javasolja, hogy Szerbia vegye figyelembe a Szakértői Bizottság megfigyeléseit és az általa tett javaslatokat, és prioritásként: [...] erősítse valamennyi regionális és kisebbségi nyelv használatát az igazságügyben és a közigazgatásban" (kiemelések tölem - B. K.) (Council of Europe - Committee of Ministers 2019).

A nemzeti kisebbségeket ért nyelvi jogsértéseket különböző szempontok mentén csoportosíthatjuk: a jogsértések gyakorisága, intenzitása, ismétlődése, területi megoszlása, elkövetője, következménye, oka stb. alapján. Ez utóbbi szempont szerint de jure és/vagy de facto jogsértésnek minősül, ha 1) két (vagy akár több) törvény konfliktusa esetén a kevésbé kisebbségbarát megoldást alkalmazzák; 2) a helyi önkormányzatok nem vezetik be a törvényi feltételeknek eleget tevő kisebbségi nyelvet hivatalos használatba, és ily módon teljesen ellehetetlenítik egy nemzeti kisebbség számára a nyelvhasználati jogok gyakorlását; 3) a jogalkalmazók nem tartják tiszteletben a nyelvi jogi rendelkezéseket vagy tévesen értelmezik azokat, ez utóbbi esetben jellemzően kiegyenlítve a (hivatalos használatban lévő) nemzeti kisebbségi nyelvet az idegen nyelvekkel; valamint 4) a megfelelő szabályozás hiányában hatástalan vagy nehézkes a tartományi rendelettel szavatolt jogok védelme.

Az előző fejezetben említett hivatalos nyelvhasználati jogok megsértéséből adódó esetleges negatív jogkövetkezményeket illetően általánosságban véve elmondható, hogy a jogalkotó igen kisszámú normasértésre irányozott elő konkrét szankciót. Például a hivatalos nyelvhasználati törvényben csak a vizuális nyelvhasználatra vonatkozó rendelkezések megszegését szankcionálja, és azt is igen 
szelektív módon. Gazdasági vétség, illetve szabálysértés miatt pénzbírságot ír elő a vállalat, intézmény, más jogi személy, valamint magánvállalkozó részére, ha a cégtáblát nem tünteti fel szerb, illetve a hivatalos használatban lévő többi kisebbségi nyelven (24-25. szakasz). A törvény utolsó módosítása (2018) előtt szintén pénzbírsággal sújtották azokat a törvényszegő szervezeteket, amelyeket a közlekedési jelzések, helység- és egyéb névtáblák kihelyezésével bíztak meg, valamint a szervek, a közmegbízatást gyakorló szervezetek felelős személyeit, ha a szerv, szervezet elnevezése nem többnyelvü táblán szerepelt. Az azóta hatályon kívül helyezett 23. és 26. szakaszt a hivatalos nyelvhasználati törvény 1991. évi eredeti változatába is már belefoglalták, és majdnem harminc év után, valószínűleg bármilyen gyakorlati implikáció nélkül, kikerült a törvény szövegéből. Természetesen ez nem jelenti, hogy a továbbiakban ne lenne kötelező feltüntetni a szervek neveit, az utcanévtáblákat kisebbségi nyelven is, de a törvény ezt szabályozó rendelkezéseinek megsértésekor mostantól nem lehet közvetlenül ezen törvény alapján pénzbírságot behajtani. Egyébként nehezen elképzelhetö, hogy erre ez idáig is lett volna példa, melyre több körülmény is rámutat.

A valamikori tartományi nyelvhasználati rendelet értelmében 2005-től kezdve a rendelet hatályon kívül helyezéséig (Tartományi képviselőházi rendelet a tartományi képviselőházi rendeletek hatályon kívül helyezéséről 2014: 1. szakasz 1. bekezdés) Vajdaság AT Végrehajtó Tanácsa (később kormánya) éves jelentésben számolt be a Tartományi Képviselőháznak a nemzetiségi nyelvek hivatalos használatának állapotáról a tartományban (Tartományi képviselőházi rendelet a nemzeti kisebbségek nyelvének és írásmódjának hivatalos használatát érintő egyes kérdések részletesebb szabályozásáról Vajdaság AT területén 2003: 10. szakasz), a Tartományi Oktatási, Jogalkotási, Közigazgatási és Nemzeti Kisebbségi - Nemzeti Közösségi Titkárság pedig 2005-től mind a mai napig pályázat útján ítél oda vissza nem térítendő pénzeszközöket, egyebek mellett a különböző többnyelvű névtáblák elkészítésére és kihelyezésére azokban az önkormányzatokban a tartomány területén, amelyekben egy vagy több kisebbségi nyelv is hivatalos használatban van. A valamikori nyelvhasználati jelentések is arról tanúskodnak, hogy a jogsértések közvetlen szankcionálása helyett inkább pályázati támogatással, a tartományi fordítószolgálat szakmai segítségével igyekeztek érvényt szerezni a vizuális nyelvhasználat terén szavatolt jogoknak. 1991 és 2002 között, amíg a nyelvhasználati rendelkezések betartása feletti felügyeletet a különböző államigazgatási szervek végezték a Vajdaságban is, jóformán nem tudunk egyetlen megtett intézkedésről sem, 2002 után pedig, amikor a tartományi szervek az Omnibusz törvény értelmében átruházott hatáskörben léptek fel, azonnali büntetés helyett inkább instrukciókat, tájékoztatást, utasításokat adtak (Tartományi Jogalkotási, Közigazgatási és Nemzeti Kisebbségi Titkárság 2006). 
A nyelvhasználati rendelet alapján összeállított utolsó, 2011. évi jelentés szerint 2011-ben 107 alkalommal folytattak közigazgatási felügyeletet, ez a szám azonban nem csak a névtáblák, feliratok ellenőrzésére vonatkozik. Viszont ebben a dokumentumban is szerepel, hogy első körben csak a jogszerütlenségek elhárítására kötelezik a jogszegőt (amelyhez a tartományi titkárság az említett pályázat útján aktívan is hozzájárul), és ha a következő vizsgálat alkalmával továbbra sem változott a helyzet, a tartományi felügyelő szabálysértési eljárást indítványoz.

Másrészről, a nyelvhasználati törvény 1992 végét jelölte meg végső határidőként, hogy a törvény hatálya alá tartozó szervek, szervezetek, jogi személyek névtábláik nyelvhasználatát összehangolják a törvény rendelkezéseivel (27. szakasz). Ahogyan olvashattuk a fentiekben, a kilencvenes évek komolyabb beavatkozások nélkül telt el, majd 2003-ban a Köztársasági Földmérö Intézet helyileg illetékes ingatlan-nyilvántartó hivatalának hatáskörébe került valamennyi köztéri elnevezés a nyelvhasználati és a kisebbségvédelmi törvénnyel összhangban történő feltüntetése, amelyre 15 éves haladékot kaptak az illetékes földhivatalok (Rendelet a házszámok meghatározásáról, az épületek számmal való megjelöléséről és a helységek, utcák és terek megjelöléséről 2003: 34. szakasz). ${ }^{7}$ A jelenleg hatályos rendeletben bár továbbra is szerepel, hogy a névtáblákat a nemzetiségi hivatalos nyelvhasználat szabályai szerint kell kitüzni, azok megsértése esetére a jogszabály nem ír elő szankciót (Rendelet a lakcím nyilvántartásáról 2017: 34. szakasz 2. bekezdés, 40. szakasz).

Az anyakönyvekről szóló törvény szintén nem szankcionálja közvetlenül a többnyelvü kivonat kiállításának az elutasítását, és szabálysértés miatt csak annak a hivatalos személynek a megbüntetését írja elő, aki a kiszabott határidőn belül nem jegyzi be a személynevet a nemzeti kisebbségi személy anyanyelvén, illetve annak helyesírása szerint az anyakönyvbe (Törvény az anyakönyvekről 2009: 87. szakasz 3. bekezdés 4) pont). Egyébként a kiszabható pénzbírság összege ebben az esetben megegyezik azon magánszemélyekre kiróható pénzbírság összegével, akik például nem határidőn belül jelentik be a születés vagy haláleset tényét ( 87 . szakasz 1. bekezdés). Láthatóan a jogalkotó nem tett különbséget azon helyzetek között, ha valaki a hivatalos munkavégzése részeként követ el jogsértést, vagy egyszerü mulasztásból/tudatlanságból.

A hivatalos nyelvhasználatról, az állami és egyéb szervek pecséteiről, illetve az anyakönyvekről szóló törvény alkalmazását az államigazgatási, egyéb állami és önkormányzati szervekben hivatalból, felsőbb utasítás vagy magánindítvány

\footnotetext{
A rendeletet először 2012-ben helyezték hatályon kívül, és az új rendeletből törölték a 15 éves türelmi időt, a kisebbségvédelmi, illetve nyelvhasználati törvényre való hivatkozást, illetve a büntető rendelkezésekben sem szerepelt a nemzetiségi nyelvü felirat elhagyásának az esete (SZK Hivatalos Közlönye, 16/2012. szám).
} 
alapján a Közigazgatási Felügyelőség ellenőrzi (Törvény a közigazgatási felügyeletről 2011:20. és 22. szakasz), melynek során, a jogsértés természetétől függően, megtilthatja a törvénnyel ellentétes cselekmények további foganatosítását, intézkedéseket indítványozhat a jogsértés következményeinek elhárítására, illetve javasolhatja a jogsértő személy ellen fegyelmi eljárás indítását (31. szakasz). Ha az ellenőrzött szerv felelős személye nem tartja tiszteletben a közigazgatási felügyelő határozatába foglaltakat, szabálysértésért pénzbírsággal sújtható (39-40. szakasz). Eszerint pedig, bár a nyelvhasználati törvényből kikerültek az idevágó büntető rendelkezések, a hivatalos nyelvhasználatról szóló törvény megsértése miatt mégiscsak kiróható egyfajta közvetett szankció. A tartományi közigazgatási szervek munkája során a hivatalos nyelvhasználat szabályainak betartását a Tartományi Kormány követi (Tartományi képviselőházi rendelet a tartományi közigazgatásról 2014: 21. szakasz), a Tartományi Oktatási, Jogalkotási, Közigazgatási, Nemzeti Kisebbségi - Nemzeti Közösségi Titkárság pedig az idevágó átruházott államigazgatási feladatokat látja el Vajdaság AT területén (37. szakasz 12. bekezdés).

Külön figyelmet érdemel a Büntetőtörvénykönyv 129. szakasza, amely önálló büncselekményként írja elő a nyelv- és íráshasználatra való jog megsértését, és pénzbírsággal vagy egy évig terjedő szabadságvesztéssel bünteti, ha „valaki a nemzetek és a Szerbiában élő nemzeti és etnikai kisebbségi közösségek nyelv- és íráshasználatára vonatkozó szabályokkal ellentétesen megrövidíti vagy korlátozza a polgárt, hogy jogainak érvényesítése vagy a hivatalos szervekkel vagy szervezetekkel való értekezése során a saját nyelvét vagy írását használja”. Ez a rendelkezés általános büntetőjogi felelősséget irányoz elő jogkövetkezményként minden olyan ügyre, amikor egy nyelvi jogot nem sikerült maradéktalanul érvényre juttatni a gyakorlatban. Tehát ide nemcsak a kisebbségi nyelvü hivatalos szóbeli, illetve írásbeli értekezés szándékos ellehetetlenítése tartozik, de a többi a hivatalos nyelvhasználati törvény alapján egyébként közvetlenül nem szankcionálható nyelvi jogsértés (például a kisebbségi nyelvü ürlapon való személyi igazolvány vagy jogosítvány, illetve egyéb kétnyelvü közokiratok kiállítására vonatkozó kérelem megtagadása, a hivatalos használatban lévő nyelven készült magánokirat [pl. szerződés] elutasítása, a választások során a kisebbségi nyelvű választási anyag előkészítésének, használatának az elmaradása stb.), valamint az általános (emberi) nyelvi jogok megsértése is. Ez utóbbi kapcsán a fenti rendelkezés gyakorlati vetületét bizonyítja a Požarevaci Gazdasági Bíróságon történt, a Kisebbségi Jogvédő Intézet éves jelentésében közzétett eset is, amikor a bíró elutasította a tanú kérelmét, hogy anyanyelvén (magyarul) nyilatkozzon, sőt, pénzbírsággal büntette, mikor a tanú következetesen megtagadta a szerb nyelvű vallomástételt megfelelő szerb nyelvtudás birtokában is. Ezért a 
Büntetőtörvénykönyv fenti szakaszára hivatkozva büntető feljelentést nyújtottak be az eljáró bíró ellen az illetékes ügyészségnél (Szilágyi 2018). Az eljárás jelenleg folyamatban van, ezért a bíró felelősségét és magának a jogsértésnek a tényét explicit verbis nem lehet még megállapítani. A perrendtartásról szóló törvény idevágó rendelkezése értelmében a felek, illetve az eljárás többi résztvevője részére szóbeli fordítást kell biztosítani, ha nem értik az eljárás nyelvét (95. szakasz 2. bekezdés). A törvényben azonban nem találunk választ arra, ki jogosult egyöntetüen kimondani, hogy a résztvevő érti-e az eljárás nyelvét vagy sem: ha a bíró, akkor saját megítélése alapján, akár indoklás nélkül is megtagadhatja az alkotmányosan szavatolt alapvető nyelvi jogok gyakorlását. Másrészröl maga az alkotmány nem köti feltételhez az anyanyelvhasználat jogát a bírósági eljárásokban, ezért a tanú akár kiváló szerb vagy egyéb nyelvtudás mellett is nyilatkozhat az anyanyelvén.

A fentieken túl mind a büntetőeljárásról szóló törvénykönyvben, mind pedig a perrendtartásról szóló törvényben súlyos eljárási szabályszegésnek minősül az alapvető nyelvhasználati jogok megsértése, amely miatt az elsőfokú ítéletre fellebbezés nyújtható be (a közigazgatási perről szóló törvény nem tartalmaz hasonló rendelkezést). Miközben azonban a büntetőeljárás során csak az számít szabályszegésnek, ha a vádlott, a védője, a károsult, illetve a magánvádló nem használhatja az anyanyelvét a fötárgyaláson, valamint annak menetét nem követheti a saját nyelvén (Törvénykönyv a büntetőeljárásról 2011: 438. szakasz 1. bekezdés 5) pont), azaz a bíróság nem biztosított tolmácsot erre a célra; addig a peres eljárásról szóló törvény szerint szabályszegés áll fenn akkor is, ha a törvényes feltételek megléte mellett az eljárást nem a hivatalos használatban lévő nemzeti kisebbségi nyelven, hanem szerb nyelven folytatták le (Törvény a perrendtartásról 2011: 374. szakasz 2. bekezdés 8) pont). Mindkét eset legfeljebb szakmai, esetleg morális szempontból „kellemetlen” az eljáró bírónak, ha a fellebbviteli bíróság esetleg ezen eljárási hiba miatt ad helyt a fellebbezésnek. Közvetlen felelősségre vonást csak a fentiekben idézett büntető rendelkezés alapján eredményezhet. A későbbiekben pedig, az ügy további kimenetelére való tekintettel, a sértett fél alkotmányos panaszt nyújthat be az alkotmánybírósághoz, amelyben kérheti az ítélet megsemmisítését, közzétételét, a káros következmények elhárítását, valamint kártérítést.

Valamennyi említett jogsértés a nemzeti kisebbségi nyelv hivatalos státusának mellőzéséből ered, amely státust a helyi önkormányzat a községi/városi statútumban ismer el. Ha viszont ez nem történik meg, a nemzeti kisebbség eleve nem is gyakorolhatja a törvény szerinti nyelvhasználati jogait. Az ún. mulasztásos alkotmány-, illetve törvénysértést azonban nem ismeri a szerbiai jog, ezért az alkotmánybíróság sem foglalkozik azokkal az ügyekkel, amikor a 
nyelvi jogsértés valójában nem tevés, mulasztás eredménye. Például Ürög község statútumának alkotmányossági és törvényességi felülvizsgálata során, amely éppen a magyar nyelv hivatalos használatba való bevezetésének az elutasításából eredt, erre a gyakorlatra hivatkozva vetette el a tárgy érdemi vizsgálatát (IUo-399/2011. ügyszámú alkotmánybírósági határozat).

\section{Zárógondolatok}

Szerbiában egy nyelvi jogi rendelkezés megsértése, amely lehet szándékos vagy véletlen mulasztás, tudatlanság vagy „kényelmesség” folyománya is, az adott jogszabálytól függően gazdasági vétségnek, szabálysértésnek, büncselekménynek, eljárási hibának minősülhet, és közvetlen szankciót (pénzbírság, szabadságvesztés) vagy egyéb, büntetésnek nem minősülö negatív jogkövetkezményt (fellebbezés, ítélet megsemmisítése, kártérítés stb.) eredményezhet. Zömmel a sértett fél tevőleges hozzáállására van szükség (kereset, [alkotmányos] panasz, indítvány benyújtása az illetékes szervhez) a jogsértés megállapítása és az esetleges jogkövetkezmények alkalmazása céljából. Emellett a nyelvi jogok tiszteletben tartásának rendszeres külső felügyeletét a közigazgatásban a Közigazgatási Felügyelőség, az illetékes tartományi titkárság, illetve az ombudsmanok is ellátják. Ez utóbbiak azonban legfeljebb ajánlást fogalmazhatnak meg a jogsértő szerv felé, amelynek a semmibevétele inkább politikai, mintsem jogi következményeket von maga után. A Polgári Jogvédő például értesítheti a közvéleményt, a parlamentet, a kormányt, esetleg felelősségre vonást indítványozhat (Törvény a Polgári Jogvédőről 2005: 31. szakasz 5. bekezdés), kötelező erejü döntést viszont nem hozhat. Ebből a szempontból az általa lefolytatható eljárás első olvasatra sokban hasonlít a tanulmányban ismertetett két nemzetközi egyezmény implementációjára vonatkozó monitoringeljárásra. Másrészről, a konkrét (nemzetközi bírói) garancia hiányától eltekintve a szakértői/tanácsadó testületek az elmúlt években olyan magas morális legitimációra tettek szert, hogy véleményük egyfajta „puha igazságszolgáltatásként” ('soft jurisprudence') is felfogható (Beco-Lantschner 2012, 123). Ezt a státust azonban a szerbiai ombudsmanoknak ez idáig nem sikerült kivívniuk.

Összegezve elmondható, hogy a nemzetiségi nyelvi jogok megsértése Szerbiában általánosságban nézve korrigálható, és közvetett vagy közvetlen módon mégiscsak szankcionálható; azonban ezen büntető rendelkezéseknek jobbára bírósági eljárásokban lehet érvényt szerezni, amelyre megfelelő felkészültség, anyagi fedezet hiányában csak kevesen vállalkoznak. Éppen ezért a magyarországi Kisebbségi Jogvédő Intézet jogsegély-hálózat keretében támogatást nyújt a határon túli magyarok jogvédelmének ellátásában fontos szerepet vállaló ügyvé- 
deknek, jogászoknak, civil szervezeteknek. A tény azonban, hogy 2013 és 2019 között a dokumentált, illetve konkrétan (anyagilag) támogatott ügyek száma a Vajdaságban éves szinten egyszer sem haladta meg a tíz esetet, azt bizonyítja, még sokat kell tenni, elsősorban a jogtudatosság növelése, az állami és egyéb szervekkel való együttmüködés és kommunikáció javítása terén.

\section{Irodalom}

Andrássy György. 2013. A nyelvszabadságról és a nyelvszabadság jelentőségéről. Létünk különszám: 7-19.

Beco, Gauthier-Lantschner, Emma. 2012. The Advisory Committee on the Framework Convention for the Protection of National Minorities (The ACFC). In Human Rights Monitoring Mechanisms of the Council of Europe. London-New York: Routledge.

Beretka Katinka. 2018. De iure potvrđenost multikulturalnog karaktera AP Vojvodine - Kritički prikaz (ne)postojećih normativnih nadležnosti autonomne pokrajine u oblasti manjinskih prava. Pravni zapisi (1): 141-161.

Beretka Katinka. 2019. Felsőfokú felvételi eljárás nemzetiségi nyelveken a Vajdaságban, avagy kiterjeszthető-e az egyetemi autonómia a tartományi autonómia kárára és vice versa. Acta Humana (2): 49-68.

Bibó István. 1934. A szankciók kérdése a nemzetközi jogban. Szeged: Szeged Városi Nyomda és Könyvkiadó részvénytársaság.

European Commission for Democracy through Law (Venice Commission). Opinion on the Constitution of Serbia. Opnion No. 405/2006. CDL-AD(2007)004. Strasbourg, 19 March 2007.

Fiala-Butora János. 2018. Implementation of the Framework Convention for the Protection of National Minorities and the European Language Charter: Unified Standard or Divergence? Hungarian Journal of Minority Studies (2): 7-21.

Guzman, Andrew-Meyer, Timothy. 2010. International Soft Law. The Journal of Legal Analysis.

Korhecz Tamás. 2009. A hivatalos nyelvhasználat jogi keretei a Vajdaságban - Szerbiában Jog és gyakorlat. Magyar Tudomány (11): 1313-1320.

Korkunov, Nikolai Mikhailovich. 2000. General Theory of Law. Washington: Beard Books.

Kovács Péter. 1995. A kisebbségi jogok nemzetközi garanciái. Magyar Kisebbség. https://epa. oszk.hu/02100/02169/00001/m950108.html (2019. okt. 25.)

Szilágyi Miklós. 2018. Egy különös nyelvi büncselekmény esete Szerbiában. In Magyarokjogvédelme a Kárpát-medencében 2018. 370-372. Budapest: Kisebbségi Jogvédő Intézet.

Tartományi Jogalkotási, Közigazgatási és Nemzeti Kisebbségi Titkárság. 2006. Jelentés a nemzeti kisebbségek nyelvének és írásának hivatalos használatához való jog megvalósulásáról Vajdaság AT-ban. Szám: 101-011-00002/04. 
Beretka Katinka: A nyelvi jogsértések szankcionálhatóságának tételes jogi...

Tartományi Polgári Jogvédő - Ombudsman. 2019. A Tartományi Polgári Jogvédő - Ombudsman Éves Jelentése a 2018. Évre. https:/www.ombudsmanapv.org/riv/attachments/ article/2142/Godisnji_izvestaj_PZG-ombudsmana_2018.pdf (2019. okt. 31.)

\section{Jogforrások}

A Szerb Köztársaság Alkotmánya [Ustav Republike Srbije]. SZK Hivatalos Közlönye, 98/2006. szám.

Büntetötörvénykönyv [Krivični zakonik]. SZK Hivatalos Közlönye, 85/2005., 88/2005. - jav., 107/2005. - jav., 72/2009., 111/2009., 121/2012., 104/2013., 108/2014. és 94/2016. szám.

Council of Europe - Committe of Ministers. Resolution CM/ResCMN(2015)8 on the implementation of the Framework Convention for the Protection of National Minorities by Serbia.

Council of Europe - Committee of Ministers. Recommendation CM/RecChL(2019)2 of the Committee of Ministers to member States on the application of the European Charter for Regional or Minority Languages by Serbia.

IU-294/2002. ügyszámú, 2005. február 24-én kelt alkotmánybírósági határozat, SZK Hivatalos Közlönye, 42/2005. szám.

IUo-199/2013. ügyszámú, 2015. április 20-án kelt alkotmánybírósági határozat.

IUo-399/2011. ügyszámú alkotmánybírósági határozat.

Keretegyezmény a Nemzeti Kisebbségek Védelméről. ETS No. 157.

Rendelet a házszámok meghatározásáról, az épületek számmal való megjelöléséről és a helységek, utcák és terek megjelöléséről [Uredba o utvrđivanju kućnih brojeva, označavanju zgrada brojevima i označavanju naseljenih mesta, ulica i trgova]. SZK Hivatalos Közlönye, 110/2003., 137/2004. és 58/2006. szám.

Rendelet a lakcím nyilvántartásáról [Uredba o adresnom registru]. SZK Hivatalos Közlönye, 63/2017. szám.

Tartományi képviselőházi rendelet a tartományi képviselöházi rendeletek hatályon kívül helyezéséről, Vajdaság AT Hivatalos Lapja, 54/2014. szám.

Tartományi képviselöházi rendelet a nemzeti kisebbségek nyelvének és írásmódjának hivatalos használatát érintő egyes kérdések részletesebb szabályozásáról Vajdaság AT területén, Vajdaság AT Hivatalos Lapja, 8/2003., 9/2003. - kiigazítás és 18/2009. - az aktus elnevezésének módosítása, és SZK Hivatalos Közlönye, 69/2010. szám - AB határozat.

Tartományi képviselőházi rendelet a tartományi közigazgatásról, Vajdaság AT Hivatalos Lapja, 37/2014. és 37/2016. szám.

Törvény a hivatalos nyelv- és íráshasználatról [Zakon o službenoj upotrebi jezika i pisama]. SZK Hivatalos Közlönye, 45/91., 53/93., 67/93., 48/94., 101/2005. - más törvény, 30/2010., 47/2018. és 48/2018. szám - jav.

Törvény a közigazgatási felügyeletről [Zakon o upravnoj inspekciji]. SZK Hivatalos Közlönye, 87/2011. szám. 
Törvény a nemzeti kisebbségek jogainak és szabadságainak védelméröl [Zakon o zaštiti prava i sloboda nacionalnih manjina]. JSZK Hivatalos Lapja, 11/2002., Szerbia és Montenegró Hivatalos Lapja, 1/2003. - Alkotmányos Alapokmány, SZK Hivatalos Közlönye, 72/2009. - másik törvény, 97/2013. - AB határozat és 47/2018. szám.

Törvény a nemzeti kisebbségek védelméről szóló keretegyezmény megerősítéséről [Zakon o potvrđivanju Okvirne konvencije za zaštitu nacionalnih manjina]. JSZK Hivatalos Lapja - Nemzetközi szerződések, 6/98. szám.

Törvény a perrendtartásról [Zakon o parničnom postupku]. SZK Hivatalos Közlönye, 72/2011., 49/2013. - AB határozat, 74/2013. - AB határozat, 55/2014. és 87/2018. szám.

Törvény a Polgári Jogvédőről [Zakon o Zaštitniku građana]. SZK Hivatalos Közlönye, 79/2005. és 54/2007. szám.

Törvény a Regionális vagy Kisebbségi Nyelvek Európai Kartájának becikkelyezéséről [Zakon o ratifikaciji Evropske povelje o regionalnim ili manjinskim jezicima]. Szerbia és Montenegró Hivatalos Lapja - Nemzetközi szerződések, 18/2005. szám.

Törvény az anyakönyvekröl [Zakon o matičnim knjigama]. SZK Hivatalos Közlönye, 20/2009., 145/2014. és 47/2018. szám.

Törvénykönyv a büntetőeljárásról [Zakonik o krivičnom postupku]. SZK Hivatalos Közlönye, 72/2011., 101/2011., 121/2012., 32/2013., 45/2013., 55/2014. és 35/2019. szám.

Utasítás az anyakönyvek vezetéséről és az anyakönyvek nyomtatványairól [Uputstvo o vođenju matičnih knjiga i obrascima matičnih knjiga]. SZK Hivatalos Közlönye, 93/2018. szám.

\section{Internetes források}

Bartha Réka. 2019. Pásztor István: Felemelő helyzetben vagyunk. Gondola.hu, máj. 8. https:// gondola.hu/cikkek/113057-Pasztor_Istvan_Felemelo_helyzetben_vagyunk.html (2019. okt. 25.)

Európa Tanács hivatalos honlapja. https://www.coe.int/en/web/minorities/serbia (2019. okt. 25.)

Ismeretlen. 2018. Szerbia rendelkezik a legjobb nemzeti kisebbségi törvénnyel. Magyar Szó, jún. 13. https://www.magyarszo.rs/hu/3703/kozelet_politika/184720/,Szerbiarendelkezik-a-legjobb-nemzeti-kisebbségi-törvénnyel”.htm (2019. okt. 25.)

Kisebbségi Jogvédő Intézet hivatalos honlapja. http://www.kji.hu/ (2019. okt. 25.)

MTI. 2019a. Szerb kormányfö: Köszönet Orbán Viktornak Magyarország mindenre kiterjedő támogatásáért. Magyar Nemzet, ápr. 15. https://magyarnemzet.hu/kulfold/szerb-kormanyfokoszonet-orban-viktornak-magyarorszag-mindenre-kiterjedo-tamogatasaert6738983/ (2019. okt. 25.)

MTI. 2019b. Magyarország és Szerbia is csak nyert a vajdasági gazdaságfejlesztési programmal. Magyarország Külgazdasági és Külügyminisztériuma, okt. 11. https://www.kormany. hu/hu/kulgazdasagi-es-kulugyminiszterium/hirek/magyarorszag-es-szerbia-is-csaknyert-a-vajdasagi-gazdasagfejlesztesi-programmal (2019. okt. 25.) 
Beretka Katinka: A nyelvi jogsértések szankcionálhatóságának tételes jogi...

Rúzsa Mária. 2019. Zenta: Hogyan igényelhetök a kétnyelvü anyakönyvi kivonatok? Vajdaság Ma, máj. 15. https://www.vajma.info/cikk/vajdasag/23676/Zenta-Hogyan-igenyelhetoka-ketnyelvu-anyakonyvi-kivonatok.html (2019. okt. 31.)

Tartományi Oktatási, Jogalkotási, Közigazgatási, Nemzeti Kisebbségi - Nemzeti Közösségi Titkárság hivatalos honlapja. http://puma.vojvodina.gov.rs/ (2019. nov. 1.)

Katinka BERETKA

\section{MOGUĆNOSTI SANKCIONISANJA POVREDA JEZIČKIH PRAVA U POZITIVNOM I MEĐUNARODNOM PRAVU}

U ovom radu, uz pomoć pravno naučnih metoda predstavljaju se pravna regulativa jezičkih prava u Srbiji i sankcije, odnosno druge negativne pravne posledice u slučaju povrede tih pravila, naročito sa aspekta službene upotrebe manjinskih jezika u okviru pozitivnog i međunarodnog prava. Pored generalne prezentacije jezičkih prava u Srbiji koja su nesumnjivo zaslužila pohvale u nekim elementima, akcenat se stavlja na kritičnu analizu eventualnih kaznenih odredaba i njihove efikasnosti, imajući u vidu nepovoljnu praksu u Srbiji koja često ostavlja protivpravno ponašanje bez ikakve posledice.

Cilj je sakupljati one pravne odredbe koje propisuju nekakvu sankciju, odnosno drugi vid pozivanja na odgovornost u slučaju povrede jezičkih prava, i po mogućnosti proceniti njihovu produktivnost u toku ostvarivanja jezičkih prava nacionalnih manjina.

Ključne reči: jezička prava, nacionalne manjine, povreda prava, sankcije, Srbija

Katinka BERETKA

\section{PROBABILITY OF SANCTION IMPOSITION FOR VIOLATION OF LINGUISTIC RIGHTS IN DOMESTIC AND INTERNATIONAL LAW}

The paper is aimed to present the legal regulation of linguistic rights in Serbia and sanctions or other negative legal consequences imposed in case of violation of these rules, especially from the aspect of official use of national minority languages both in domestic and international legal framework. Besides presentation of language rights that are rightly honoured in many elements, the accent is put on critical analysis of probable sanctions provisions and their efficiency, with special regard to the not so much fair legal practice in Serbia that in most of the cases leaves the wrong without any legal consequences.

The goal is to round up those legal provisions that regulate any kind of sanctions or other ways of impeachment in case of violation of linguistic rights, and to evaluate, as far as possible, their productivity in process of enforcement of national minority language rights. Keywords: linguistic rights, national minorities, violation of rights, sanction, Serbia 